\title{
Using otolith microstructure to analyse growth of juvenile Baltic cod Gadus morhua
}

\author{
K. Hüssy ${ }^{1, *}$, H. Mosegaard ${ }^{1}$, H.-H. Hinrichsen ${ }^{2}$, U. Böttcher ${ }^{3}$ \\ ${ }^{1}$ Danish Institute for Fisheries Research, Charlottenlund Castle, 2920 Charlottenlund, Denmark \\ ${ }^{2}$ Dept. Fishery Biology, Institute for Marine Research, University of Kiel, Düstenbrooker Weg 20, 24105 Kiel, Germany \\ ${ }^{3}$ Institute for Baltic Sea Fisheries, An der Jägerbäk 2, 18069 Rostock, Germany
}

\begin{abstract}
Pelagic and demersal juvenile Baltic cod Gadus morhua L. were collected on the slope and the top of Rønne bank in the Baltic Sea during 2 cruises in November and December 1998. The growth, age at settling and vertical migration pattern were studied by otolith microstructure analysis. The relationship between fish and otolith size were found to change at settling, with an increase of fish size in relation to otolith size after settling. This change was more pronounced on the slope compared to the top of the bank. The timing of first settling at the 2 localities did not differ with respect to fish age. At both localities, fish that hatched early in the season spent a shorter time in the pelagic stage than late-hatched fish. However, significant differences in growth rate during the pelagic stage were observed, where fish captured on the slope grew faster. On the bank, individuals with fast otolith growth rates before settling continued to grow fast after settling. On the slope, no relationship between growth before and after settling was found. These results indicate that the different settling habitats occupied by juvenile Baltic cod have different potential for settling and nursery areas.
\end{abstract}

KEY WORDS: Baltic Sea $\cdot$ Juvenile cod $\cdot$ Otolith microstructure $\cdot$ Growth $\cdot$ Settling behaviour Resale or republication not permitted without written consent of the publisher

\section{INTRODUCTION}

During their first year of life, Baltic cod Gadus morhua L. undergo a series of life stages, from the egg to yolk-sac larva, and larva to the pelagic and demersal juvenile stages. During these early life stages, mortality is extremely high in gadoid fish, decimating numbers by as much as $99.9 \%$ (Houde 1987, Rice et al. 1993, Cushing \& Horwood 1994). Baltic cod have an extended spawning period, from March through to September (Bagge \& Thurow 1993, Wieland \& Zuzarte 1996). From the Bornholm Basin, Denmark, cod larvae and pelagic juveniles can be transported into nearshore areas below the Ekman layer, where they make the transition to the demersal life stage (Hinrichsen et al. 1997, 2001, Voss et al. 1999).

During the transport from spawning to juvenile nursery areas, survival is determined primarily by predation, the temporal match between larval hatching and the production of their zooplankton prey, as well as advection and retention of fish in favourable environ- ments (e.g. Hjort 1914, Cushing 1972, Lasker 1981, Sissenwine 1984, Bailey \& Houde 1989, Miller 1997). For Baltic cod, hatching and the early larval stage have been identified as two of the most critical periods (Köster et al. 2001), where density-independent processes like predation, cannibalism and food availability control larval survival (Cushing 1983, Fortier \& Villeneuve 1996).

However, variability in the density-independent component of early life mortality is small (Myers \& Cadigan 1993b), and abundances of eggs and larvae are seldom a good predictor of recruitment (Sissenwine 1984, Smith 1985, Peterman et al. 1988, Campana 1996). While the mechanisms regulating survival of larvae and pelagic juveniles may be predominantly density-independent, density-dependent mechanisms seem to take over during and after settling (Sundby et al. 1989, Myers \& Cadigan 1993a).

In coral reef fishes, as in the demersal stage of a wide range of species, strong density-dependent competition for territories with shelter and favourable feeding 
conditions at settling is well known. This competition either affects survival of newly settled fish directly (e.g. Sissenwine 1984, Forrester 1990, Tupper \& Hunte 1994, Carr \& Hixon 1995, Tupper \& Boutilier 1995a,b, Van der Veer et al. 1997), or regulates the size of the adult population by affecting the time until juveniles reach maturity (Jones 1987). Survival of pre-recruits is thus determined by an interaction of predation with other processes, such as competition for food and suitable habitat. A number of studies show that as fish grow, they pass through prey fields of various predators (e.g. Folkvord \& Hunter 1986, Post \& Evans 1989a), and that both the number of potential predators and the mortality they cause decrease with increasing fish size (Zijlstra et al. 1982, Van der Veer et al. 1996, Miller 1997).

The key driving force behind enhanced survival success, according to these theories, is growth. Even small changes in growth rate may affect survival considerably (Houde 1987, Rice et al. 1993, Campana 1996, Meekan \& Fortier 1996). Analyses of growth patterns may thus provide insight into the mechanisms regulating survival of fish, as well as the suitability of different habitats as nursery areas.

In the Baltic, the biomass of the primary copepod prey species of pelagic cod increases steadily from $<100 \mathrm{mg} \mathrm{m}^{-3}$ in January to ca. $900 \mathrm{mg} \mathrm{m}^{-3}$ in July, and decreases dramatically during August/September, down to levels found in winter (Möllmann et al. 2000). Depending on hatch date, transport conditions and settling habitat, the individuals experience widely different environmental conditions, providing the foundation for widely varying growth and survival rates.

The main objectives of this study were to examine growth of juvenile Baltic cod from the pelagic stage through the transition to the early demersal stages, using otolith microstructure analysis. Particularly, the timing of settling in relation to hatch date and growth during the pelagic stage and the effect of pelagic growth rate on growth during the demersal stage was investigated. The effect of settling habitat on growth was also evaluated by comparison of growth between a deep locality with a temperature-stratified water column on the slope of the Bornholm Basin and a shallow, vertically mixed locality on the Oder bank.

\section{MATERIALS AND METHODS}

Field samples. A total of 82 pelagic juvenile Baltic cod were collected with RV 'Solea' on 3 to 5 November, of which a subsample of 20 fish was selected (see also Hüssy et al. 2003, this issue). In all, 169 demersal juvenile Baltic cod were collected with RV 'Dana' on 8 December in a shallow area on Oder bank (density: 0.3 ind. $\mathrm{m}^{-2}$ ) and 105 juveniles in a deeper area on the slope of the Bornholm Basin (density: 0.2 ind. $\mathrm{m}^{-2}$ ) (see Hüssy et al. 2003). For analysis, a random subsample of 50 fish was selected from each area.

On the bank, the water column was mixed virtually throughout the year, with temperatures decreasing from approximately 14 to $4.5^{\circ} \mathrm{C}$ in the investigated time period. Data were not available from Day of Year 334 onward, but were extrapolated linearly to measured values from the December cruise. On the slope, a strong thermocline developed around Day of Year 120 , with $14^{\circ} \mathrm{C}$ in the surface and $5^{\circ} \mathrm{C}$ at the bottom and persisted approximately until Day 290. After Day of Year 320, an inverse thermocline, with cold water above warmer bottom water, developed and persisted until the day of capture. A detailed description of the geographical location, water depth and hydrography on these localities, hereafter called bank and slope, is given in Hüssy et al. (2003). The same random subsample of 50 fish from that study was also used in the present work.

After capture, the fish were immediately frozen at $-20^{\circ} \mathrm{C}$. Upon thawing, standard length (SL) was measured to the nearest $0.5 \mathrm{~mm}$, and fish weighed to the nearest $0.01 \mathrm{~g}$ after drying at $60^{\circ} \mathrm{C}$ for $48 \mathrm{~h}$ (dry weight; DW). Sagittal otoliths, hereafter called otoliths, were extracted, rinsed in water and stored in labelled plastic bags.

Otolith treatment. After weighing to the nearest $\mu \mathrm{g}$ (otolith weight; OW), otoliths were ground and polished to a thickness of approximately $80 \mu \mathrm{m}$ following the method described in Hüssy et al. (2003). Otoliths were analysed using an image analysis system (Image Pro, Version 4) with a microscope coupled to a monitor screen by a CCD camera and a frame grabber. The digitised images were saved as TIFF-files in black and white. Total length from the nucleus to the edge (otolith length; OL) was measured along the longest distance from the nucleus to the tip of the rostrum at a magnification corresponding to $6.4 \mu \mathrm{m}$ pixel $^{-1}$. Measurements taken at different positions in the frontal lobe were scaled to total rostral length. Increment widths were analysed along a profile of grey values increasing from 0 (pure black) to 255 (pure white), with the 'caliper' tool of Image Pro using a profile width of $50 \mu \mathrm{m}$ and a magnification corresponding to $2.2 \mu \mathrm{m}$ pixel $^{-1}$. This tool identifies recurring patterns based on the residuals from a running average. The start of an increment was defined as the point at which the grey values changed at the fastest rate towards higher values (higher transparency). Increments were measured, and numbered, from the formation of the accessory primordia towards the edge (terminology see Campana \& Neilson 1985). The daily formation periodicity of incre- 
ments obtained using this method could not be rejected (Hüssy et al. 2003), and increments were therefore assumed to be daily.

Intervals of similar increment structure were identified using the method based on the difference between running averages of consecutive increment widths described in Hüssy et al. (2003, see 'Increment structure in field samples', p 246): average( IW $_{\mathrm{i}-10}$ to $\left.I_{\mathrm{i}}\right)$ - average $\left(\mathrm{IW}_{\mathrm{i}}\right.$ to $\left.\mathrm{IW}_{\mathrm{i}+10}\right)$. The first change in increment patterns was assumed by these authors to be correlated with time of settling, because: (1) juveniles caught in November did not have a change in increment widths, (2) the fish from the December sample that had settled before the November cruise, and therefore could not be caught with pelagic trawls, had a change in increment width (see 'Results'), (3) the backcalculated fish size at first pattern change in the December sample corresponded well with observed fish sizes at settling (see Hüssy et al. 2003). Increments between the accessory primordia and this first change in increment structure were called pelagic increments; those formed after the change were called demersal increments. Numbers of increments within the 2 intervals were recorded. OL at formation of accessory primordia was calculated as OL $-\sum\left(\mathrm{IW}_{\mathrm{i}}\right)$ and OL at increment pattern change as OL $-\sum\left(\mathrm{IW}_{\text {demersal }}\right)$.

Since all fish were assumed to originate from the same cohort, samples were pooled to result in a better model for fish DW:

$$
\ln (\mathrm{DW})=a+b \cdot \ln (\mathrm{OW})+c \cdot \ln (\mathrm{OW})^{2}
$$

where $a=-2.025, b=0.924$ and $c=0.094\left(\mathrm{df}=119, \mathrm{r}^{2}=\right.$ 0.96). Correspondingly, fish length was best described by the model:

$$
\ln (\mathrm{SL})=d+e \cdot \ln (\mathrm{OL})+f \cdot \ln (\mathrm{OL})^{2}
$$

where $d=7.550, e=-1.776, f=0.182\left(\mathrm{df}=119, \mathrm{r}^{2}=\right.$ $0.97)$. Fish size at settling $\left(\mathrm{SL}_{\text {settling }}\right)$ was therefore back-calculated assuming a proportional relationship between otolith size and fish size over time:

$$
\begin{aligned}
& \ln \left(\mathrm{SL}_{\text {settling }}\right)= \\
& \quad \ln \left(\mathrm{SL}_{\text {catch }}\right) \times \frac{d+e \cdot \ln \left(\mathrm{OL}_{\text {settling }}\right)+f \cdot \ln \left(\mathrm{OL}_{\text {settling }}\right)^{2}}{d+e \cdot \ln \left(\mathrm{OL}_{\text {catch }}\right)+f \cdot \ln \left(\mathrm{OL}_{\text {catch }}\right)^{2}}
\end{aligned}
$$

Statistical analysis. Measurements of fish length and weight, OL and OW of the field sample were tested for normality using the Kolmogorov-Smirnov 1sample test. Normally distributed data of fish length and weight and OL and OW were then compared using 1-way ANOVA, while non-normally distributed data were analysed using Wilcoxon rank sum test for equality of means. The frequency distributions of fish ages were compared using Wilcoxon signed rank test for paired observations. Regression coefficient and intercepts of regressions were compared using ANCOVA. Significance levels were set at $\mathrm{p}=0.05$. The number of observations were 20 for the November sample and 50 for both slope and bank of the December samples.

\section{RESULTS}

\section{Differences between localities at catch}

The analysis of fish length, DW, OL and OW of the December samples showed significant differences between the 2 localities: juveniles from the slope were larger/heavier (both $\mathrm{p}<0.001$, df $=98$ ), and had larger/heavier otoliths than juveniles from the bank (both $\mathrm{p}<0.001$, df $=98$ ). Their age distributions (age from accessory primordia to edge), however, did not differ ( $p=0.72$, Table 1). Subtracting the $34 \mathrm{~d}$ between the 2 cruises from the number of juvenile days and the sum of the outermost 34 increments from OL of fish from the December samples yielded an age distribution that did not differ significantly from the November sample ( $p=0.70$ ) (Fig. 1). Juveniles from the 2 cruises can therefore be assumed to be derived from the same cohorts of fish.

Between the 2 localities of the December sample, significant differences were found in the intercept and regression coefficient of the $\ln (\mathrm{DW})=a+b \times \ln (\mathrm{OW})$ relationship $(p<0.05, d f=96)$. Significant differences were also found between the regression coefficients of the 2 demersal samples and the pelagic November sample (both $\mathrm{p}<0.001$, $\mathrm{df}=66$ ) (Fig. 2). This is probably caused by an ontogenetic change in the otolith 


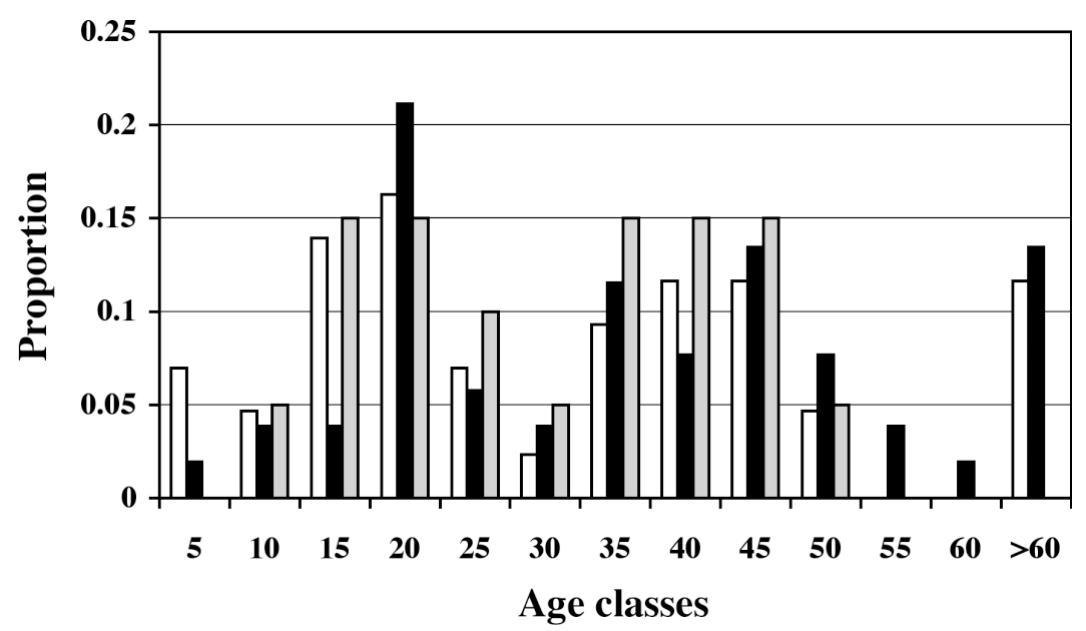

Fig. 1. Gadus morhua. Frequency distributions of fish age from the accessory primordia to the edge at capture of the November sample (grey columns), and the December samples, back-calculated to the date of the November sample (black columns: slope; white columns: bank)

size-fish size relationship, resulting in higher somatic growth in relation to otolith growth after settling to the demersal habitat.

\section{Pelagic life-stage and settling period}

The 2 areas did not differ with respect to OL at formation of accessory primordia $(p=0.55)$. The number of days from the accessory primordia to settling and the corresponding otolith growth rates were analysed in relation to average date of pelagic increment formation. The pelagic phase duration (number of days in first increment pattern interval) was significantly and positively correlated with average Day of Year of increment formation, showing that early spawned juveniles settled at a younger age than those which were late spawned. Intercept and slope of these regressions did not differ significantly between the 2 localities (both $<0.05$, $\mathrm{df}=49$ ) (Fig. 3).

Since the number of days in the pelagic stage did not differ between the 2 localities, the corresponding average increment widths were regressed on average Day of Year of increment formation. This revealed a significant, negative correlation for the bank locality $(\mathrm{p}<0.001, \mathrm{df}=$ 49). Excluding the 6 latest settled individuals, whose increments may have been affected by an ontogenetically determined decrease in width from the analysis did not change the result $(\mathrm{p}<0.001, \mathrm{df}=43)$. This means that the earlier in the season that fish are spawned, the wider their increments. On the slope locality this correlation was also negative, but not significant $(p=0.056, d f=49)$. In the context of this paper, this presumably temperatureinduced decline in increment width is not interesting. More importantly, comparisons showed that throughout the pelagic stage, increments of fish caught on the bank were significantly smaller than fish caught on the slope $(\mathrm{p}<0.01$, $\mathrm{df}=96)$ (Fig. 4).

These results indicate that early spawned fish settle at a younger age than fish spawned later in the year. On the slope, fish settled at the same age as those on the bank, but had faster otolith growth rates. The settling pattern of the 2 localities is shown in Fig. 5, represented as proportion of settled individuals in relation to date, days after formation of accessory primordia, and fish size in $\mathrm{mm}$ (Fig. 5a,b and $\mathrm{c}_{\text {, }}$ respectively).

\section{Demersal life stage}

Average growth rates during the demersal stage were calculated as $\left(\mathrm{SL}_{\text {catch }}-\mathrm{SL}_{\text {settling }}\right) /$ days in demersal stage. The proportional distribution of demersal growth rates shows that during the demersal stage, fish on the bank experienced slower somatic growth than those on the slope (Fig. 6). At settling, fish from the

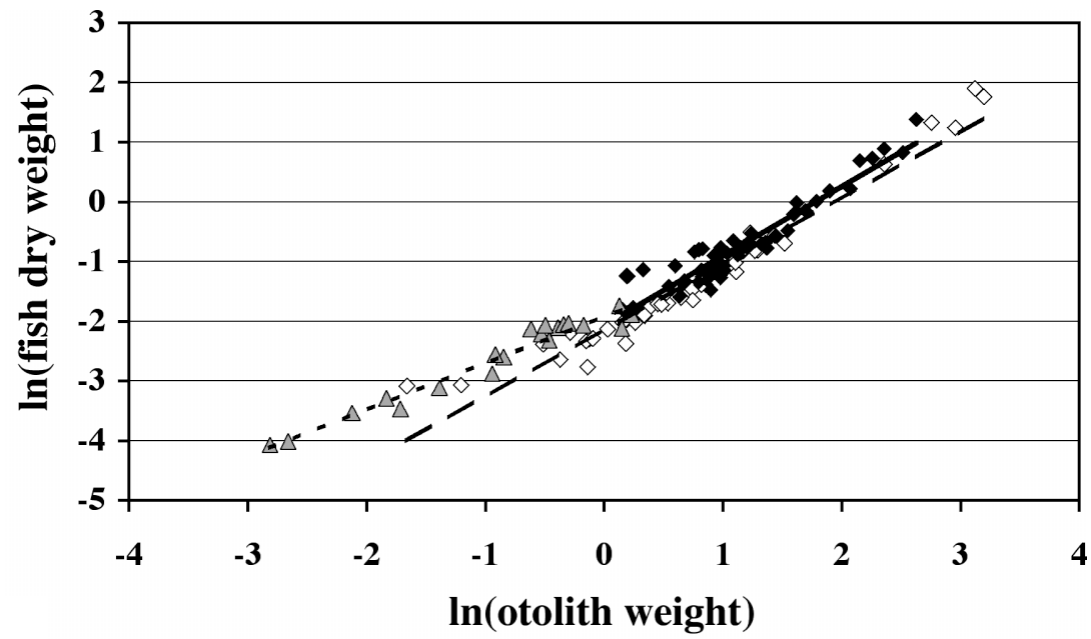

Fig. 2. Gadus morhua. Relationship between fish dry weight $(\mathrm{g})$ and otolith weight $(\mathrm{mg}) . \Delta$ : pelagic stage; $\diamond$ : bank; $\diamond$ : slope; dotted line: pelagic stage, $\ln (\mathrm{DW})=-1.91+0.78 \cdot \ln (\mathrm{OL}), \mathrm{r}^{2}=0.96, \mathrm{p}=<0.001 ;$ solid line: slope, $\ln (\mathrm{DW})=$ $-2.33+1.48 \cdot \ln (\mathrm{OL}), \mathrm{r}^{2}=0.91, \mathrm{p}<0.001$; broken line: bank, $\ln (\mathrm{DW})=-2.14+$ $1.09 \cdot \ln (\mathrm{OL}), \mathrm{r}^{2}=0.95, \mathrm{p}<0.001$ 


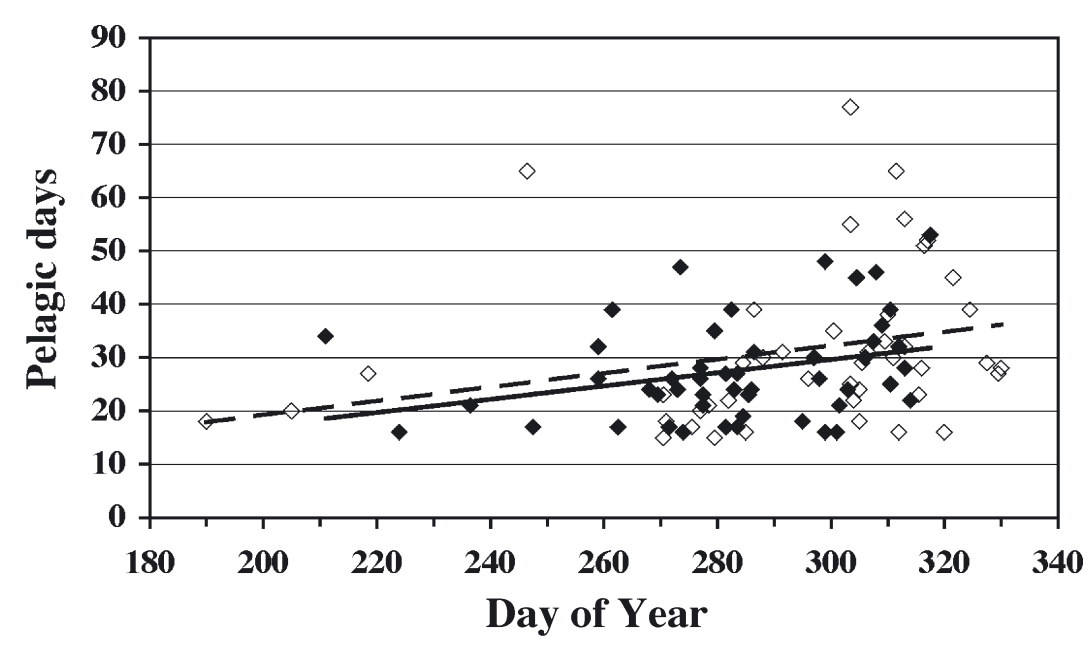

Fig. 3. Gadus morhua. Number of days spent in the pelagic stage in relation to average date of increment formation. $\boldsymbol{\Delta}$ : slope; $\diamond$ : bank; solid line: slope, Pelagic Days $=-7.562+0.124 \times$ Day of Year, $\mathrm{r}^{2}=0.096, \mathrm{p}=0.026$; broken line: bank, Pelagic Days $=-7.441+0.132 \times$ Day of Year, $r^{2}=0.054, p=0.043$. Common regression: Pelagic Days $=-9.755+0.136 \times$ Day of Year, $r^{2}=0.09, p=0.003$

slope had significantly larger otoliths than fish from the bank, although they were of similar age. The observed difference in otolith size between the 2 localities increased from the time of settling (average of $62 \mu \mathrm{m}$ ) to capture (average of $179 \mu \mathrm{m}$ ).

A significant difference in OL back-calculated to Day of Year 290 (breakdown of thermocline) was observed between the 2 localities (average of $144 \mu \mathrm{m}$, $\mathrm{p}<0.01$, df =96). However, this difference between OL at the 2 localities was similar to the one observed at catch (average of $179 \mu \mathrm{m}$, see Table 1). Growth rates of slope cod otoliths must therefore have been faster than bank cod otoliths during the time before the breakdown of the thermocline.

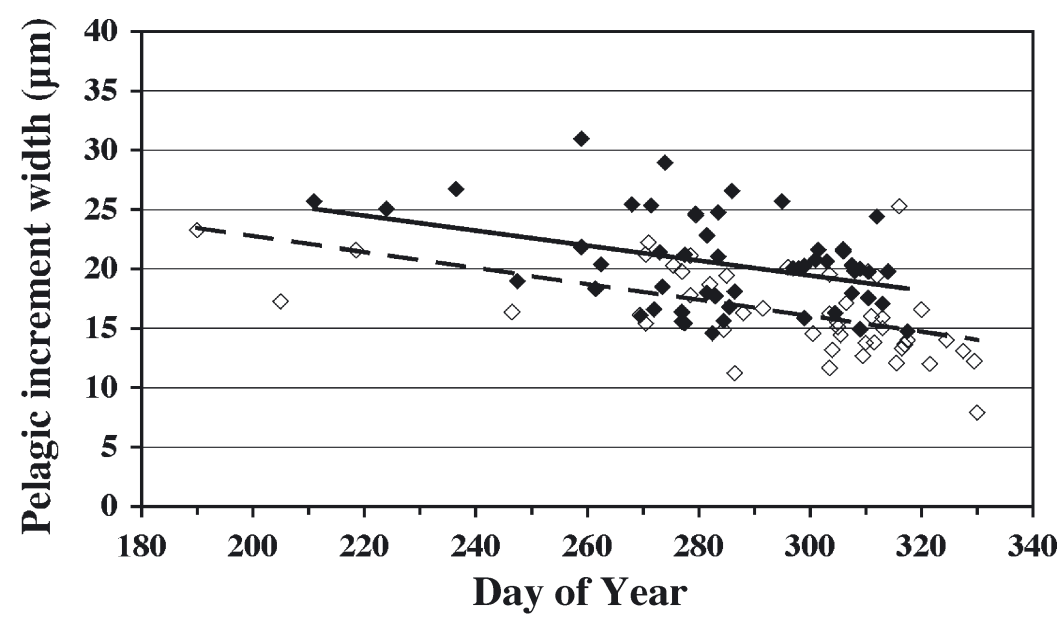

Fig. 4. Gadus morhua. Average increment widths $(\mathrm{mm})$ of the pelagic stage in relation to average date of formation. $\diamond$ : slope; $\diamond$ : bank; solid line: slope, average IW $=32.87-0.044 \times$ Day of Year, $\mathrm{r}^{2}=0.07, \mathrm{p}=0.0563$; broken line: bank, average IW $=36.47-0.068 \times$ Day of Year, $\mathrm{r}^{2}=0.24, \mathrm{p}=0.00064$

\section{Coupling between growth rates at settling and size at catch}

The effect of fast growth during the pelagic stage on fish size at capture was assessed using the residuals from the increment width-day of formation regression (Fig. 6), assuming that fish with positive residuals had experienced fast otolith growth and fish with negative residuals slow otolith growth. The residuals from the 2 localities (resid $_{\text {bank }}$ and resid $_{\text {slope }}$ ) were regressed against fish DW at capture. A significant, positive correlation was found for the bank sample: resid $_{\text {bank }}=-0.6955+3.6012 \times$ DW ( $\mathrm{p}<0.01$, df $=49, \mathrm{r}^{2}=0.17$ ), while growth rate before settling had no effect on fish size at capture on the slope: resid $_{\text {slope }}=-0.8591+1.4176 \times \mathrm{DW}(\mathrm{p}=$ 0.17, $\left.\mathrm{df}=49, \mathrm{r}^{2}=0.04\right)$.

\section{DISCUSSION}

In the present study, early spawned Baltic cod were found to make the transition to the demersal habitat at a younger age than their late-spawned conspecifics. Fish with the best match between hatchdate timing and maximal zooplankton biomass may thus experience the fastest growth rates, which leads to early settling and promotes better survival according to the 'match-mismatch' (Cushing 1972) and 'stage duration' hypotheses (Houde 1987). The spawning date/age-dependent settling pattern was the same at both localities. However, fish settling on the slope had wider pelagic increment widths throughout the season, indicating that these fishes had grown faster. These results suggest growth-rate-related differences in settling habitat, mediated by either preferences in settling habitat, differential size-specific mortality rates, or an interaction between growth and mortality.

\section{Preferences in settling habitat}

Baltic juvenile cod have been observed to undertake exploratory migrations into deeper water layers as early as at the pelagic stage (Böttcher et al. 1998). The observed segregation 

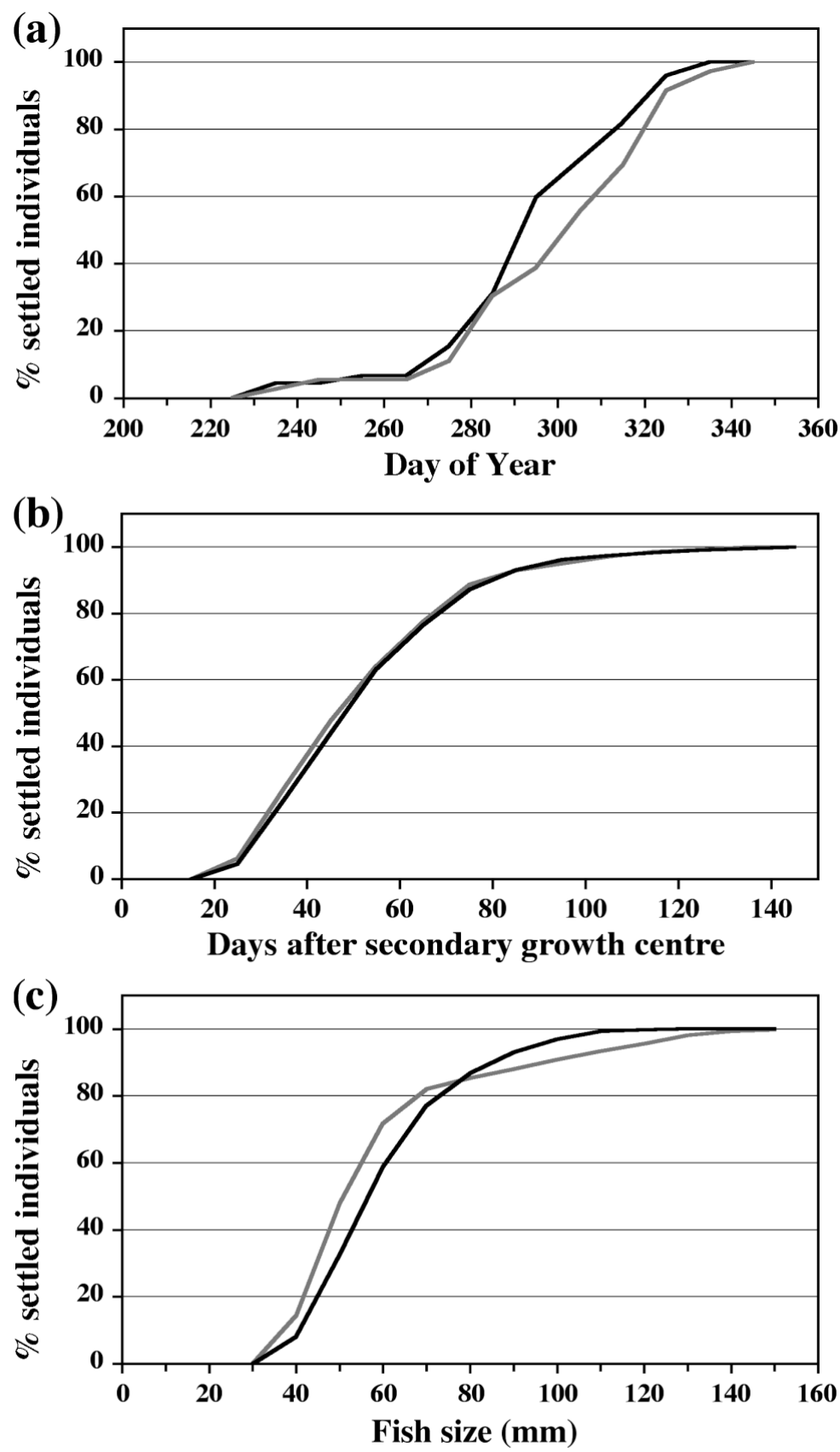

Fig. 5. Gadus morhua. Cumulative proportion of settled juvenile cod in relation to (a) Day of Year, (b) days after formation of the accessory primordia and (c) fish length. Black line: slope; grey line: bank

one of the driving forces regulating the timing of and size at settling (Salvanes et al. 1994). Due to changes in mortality and growth rates, the mortality:growth ratio increases with time and fish size, which may induce the juvenile fish to switch to a habitat with a lower mortality: growth ratio (Salvanes et al. 1994). Therefore, differential predation-induced mortality may have caused the observed settling patterns. In the juveniles examined in this study, no difference in time spent in the pelagic stage was observed, and predation-induced differences in the settling pattern would therefore have to occur during the demersal stage. However, the distributions of juvenile and adult cod, their only predator in the Baltic Sea, are spatially segregated (Aro 1989, Sparholt et al. 1991), and cannibalism is therefore limited (Uzars \& Pliksh 2000). Predation-related mortality therefore seems an unlikely explanation for the observed settling pattern.

\section{Interaction between growth and mortality}

After settling, the fish size-otolith size relationship changed. Such changes have previously been associated with ontogenetic development from one life stage to another (Hare \& Cowen 1995, Rogers et al. 2001) and may be caused by a stage-specific, more cost-effective, increase in prey size (Mittelbach 1983). At capture, fish and otoliths were significantly smaller on the bank, and the difference in otolith size between the 2 areas increased after settling. Also, the regression coefficient of the fish size-otolith size relationship was significantly smaller in the bank sample, indicating slower somatic growth compared to the slope (Secor \& Dean 1989). At least 2 mechanisms may have caused these differences: differential temperature regimes or prey availability.

\section{Temperature}

may therefore occur if juveniles with faster growth rates select different habitat types for settling, in this case the deeper slope.

\section{Size-specific mortality}

In Norwegian Atlantic cod, the relationship between predation-induced mortality and growth seems to be
Below the temperature for optimal growth, otolith growth rate increases proportionally with somatic growth rate (Marshall \& Parker 1982, Mosegaard \& Titus 1987, Mosegaard et al. 1988); higher temperatures lead to a decoupling between the 2 growth rates (Mosegaard \& Titus 1987). However, a temperaturemediated decoupling during the demersal stage can be excluded, since temperatures never exceeded $14^{\circ} \mathrm{C}$ at both localities. 


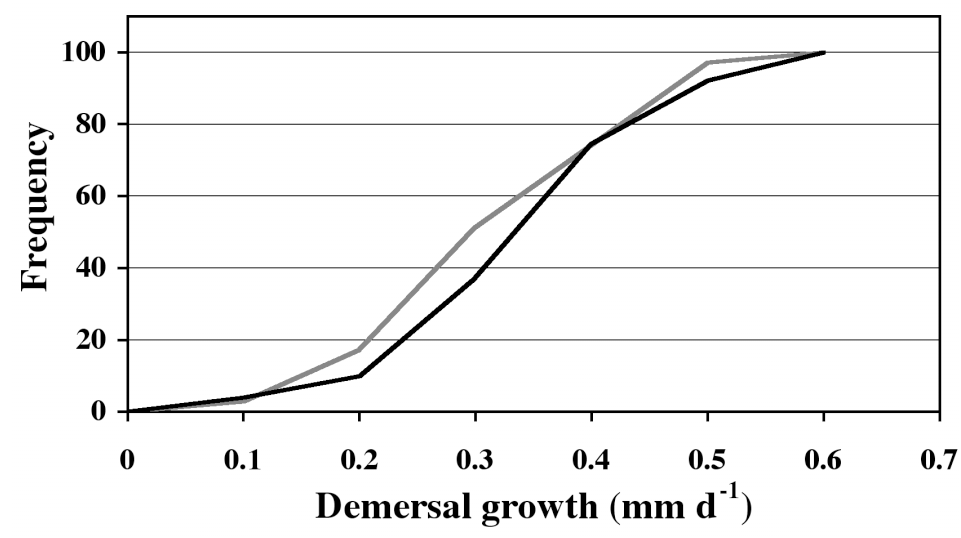

Fig. 6. Gadus morhua. Cumulative growth frequencies of juvenile Baltic cod during the demersal stage on the 2 localities investigated. Black line: slope; grey line: bank

\section{Prey availability}

The diversity of potential prey species in the Baltic Sea is limited, forcing newly settled cod to feed on the same size-range and species of prey as fish of a larger size (Hüssy et al. 1997). The major prey items during the first months of the demersal stage are benthic and semi-benthic invertebrates such as mysids and amphipods (Hüssy et al. 1997), whose highest densities are found below $25 \mathrm{~m}$ (Aschan 1988, Hansson et al. 1990, Rudstam \& Hansson 1990). On the slope, feeding conditions may therefore have been more favourable than on the shallow bank due to greater variety and quantity of prey items, as suggested by Hüssy et al. (1997). Since the density of juvenile cod was also lower on the slope, and mortality due to predation is negligible (Uzars \& Pliksh 2000), density-dependent competition for food may have been a mechanism responsible for the observed differences in growth.

Juvenile Atlantic cod become territorial after settling, defending territories in association with shelter sites (Tupper \& Boutilier 1995a,c), which results in sizeselective growth, mediated by strong density-dependent competition, not just for food resources but also for shelter sites (Tupper \& Boutilier 1995a,c). No knowledge exists of the behaviour in demersal juvenile Baltic cod, but our results agree with the finding of Tupper \& Boutilier (1995a,c): in Baltic cod, late-spawned fish experienced a prolonged pelagic stage, and fast pelagic growth entailed fast demersal growth on the bank, but not on the slope.

However, no differences in growth occurred between the 2 localities after the breakdown of the thermocline on the slope until capture, apparently linking the better growth conditions on the slope with the existence of the thermocline. Extensive daily verti- cal migrations are well known in juvenile Atlantic (Perry \& Neilson 1988, Lough et al. 1989, Lough \& Potter 1993) and Baltic cod (Böttcher et al. 1998). Comparison between observed otolith growth rates, with growth rates estimated under different assumptions of juvenile behaviour, indicated that juvenile cod from the slope were in fact undertaking daily vertical migrations (Hüssy et al. 2003). These migrations are thought to maximise consumption (Bromley \& Kell 1995) and to regulate the fish's energy budget (Javaid \& Anderson 1967, Mac 1985, Neverman \& Wurtsbaugh 1994, Sogard \& Olla 1996) and may promote differential growth rates.

Mortality during the first winter is highest in small fish of a variety of species (Post \& Evans 1989b, Cargnelli \& Gross 1996, Gotceitas et al. 1999). Attaining as big a size as possible before the onset of winter is therefore of vital importance for juvenile cod. The results from this investigation suggest that the time of hatch, growth during the pelagic stage and the habitat selected for settling are some of the key factors for survival of juvenile Baltic cod.

Acknowledgements. Financial support from the University of Copenhagen and the Danish Institute for Fisheries Research is gratefully acknowledged. We thank Skretting a/s Denmark for providing food pellets for the experimental part of this work. The present work was carried out with financial support from the Commission of the European Communities, Agriculture and Fisheries (AIR and FAIR), specific RTD programme CT98-3959 STORE as a contribution to CT97-3805 SAP. This paper does not necessarily reflect the views of the Commission. Finally, we would like to thank 3 anonymous reviewers for their helpful comments on a previous version of the manuscript.

\section{LITERATURE CITED}

Aro E (1989) A review of fish migration patterns in the Baltic. Rapp P-V Réun Cons Int Explor Mer 109:72-96

Aschan M (1988) Soft bottom macrobenthos in a Baltic archipelago: spatial variation and optimal sampling strategy. Ann Zool Fenn 25:153-164

Bagge O, Thurow E (1993) The Baltic cod stock, fluctuations and the possible causes. ICES Mar Sci Symp 198:254-268

Bailey KM, Houde ED (1989) Predation on eggs and larvae of marine fishes and the recruitment problem. Adv Mar Biol 25:1-83

Böttcher U, Oeberst R, Mieske B (1998) Daily vertical migration patterns of Baltic 0-group cod. ICES CM 1998/J:9

Bromley PJ, Kell LT (1995) Vertical migration patterns and spatial distribution of pelagic 0-group gadoids (cod, haddock, whiting and Norway pout) in the North Sea. ICES CM 1995/G:27

Campana SE (1996) Year-class strength and growth rate in young Atlantic cod Gadus morhua. Mar Ecol Prog Ser 135: $21-26$ 
Campana SE, Neilson JD (1985) Microstructure of fish otoliths. Can J Fish Aquat Sci 42:1014-1032

Cargnelli LM, Gross MR (1996) The temporal dimension in fish recruitment: birth date, body size, and size-dependent survival in a sunfish (bluegill: Lepomis macrochirus). Can J Fish Aquat Sci 53:360-367

Carr MH, Hixon MA (1995) Predation effects on early postsettlement survivorship of coral-reef fishes. Mar Ecol Prog Ser 124:31-42

Cushing DH (1972) The production cycle and the numbers of marine fish. Symp Zool Soc Lond 29:213-232

Cushing DH (1983) Are fish larvae too dilute to affect the density of their food organisms? J Plankton Res 5:847-854

Cushing DH, Horwood JW (1994) The growth and death of fish larvae. J Plankton Res 16:290-300

Folkvord A, Hunter JR (1986) Size-specific vulnerability of northern anchovy Engraulis mordax larvae to predation by fishes. Fish Bull US 84:859-869

Forrester GE (1990) Factors influencing the juvenile demography of a coral reef fish. Ecology 71:1666-1681

Fortier L, Villeneuve A (1996) Cannibalism and predation on fish larvae by larvae of Atlantic mackerel, Scomber scombrus: trophodynamics and potential impact on recruitment. Fish Bull 94:268-281

Gotceitas V, Methven DA, Fraser S, Brown JA (1999) Effects of body size and food ration on over-winter survival and growth of age-0 Atlantic cod, Gadus morhua. Environ Biol Fish 54:413-420

Hansson S, Larsson U, Johansson S (1990) Selective predation by herring and mysids, and zooplankton community structure in a Baltic Sea coastal area. J Plankton Res 12:1099-1116

Hare JA, Cowen RK (1995) Effect of age, growth rate, and ontogeny on the otolith size-fish size relationship in bluefish, Pomatomus saltatrix, and the implications for back-calculation of size in fish early life history stages. Can J Fish Aquat Sci 52:1909-1922

Hinrichsen HH, Lehman A, St. John M, Brügge B (1997) Modeling the cod larvae drift in the Bornholm Basin in summer 1994. Cont Shelf Res 17:1765-1784

Hinrichsen HH, St. John M, Aro E, Grønkjær P, Voss R (2001) Testing the larval drift hypothesis in the Baltic Sea: retention versus dispersion caused by wind-driven circulation. ICES J Mar Sci 58:973-984

Hjort J (1914) Fluctuations in the great fisheries of northern Europe viewed in the light of biological research. Rapp P-V Réun Cons Int Explor Mer 20:1-228

Houde ED (1987) Fish early life dynamics and recruitment variability. Am Fish Soc Symp 2:17-29

Hüssy K, St. John MA, Böttcher U (1997) Food resource utilization by juvenile Baltic cod Gadus morhua: a mechanism potentially influencing recruitment success at the demersal stage? Mar Ecol Prog Ser 155:199-208

Hüssy K, Mosegaard H, Hinrichsen HH, Böttcher U (2003) Factors determining variations in otolith microincrement width of demersal juvenile Baltic cod Gadus morhua. Mar Ecol Prog Ser 258:243-251

Javaid MY, Anderson JM (1967) Influence of starvation on selected temperature of some salmonids. J Fish Res Board Can 24(7):1515-1519

Jones GP (1987) Competitive interactions among adults and juveniles in a coral reef fish. Ecology 68:1534-1547

Köster FW, Hinrichsen HH, St. John MA, Schnack D, MacKenzie BR, Tomkiewicz J, Plikshs M (2001) Developing Baltic cod recruitment models. II: Incorporation of environmental variability and species interaction. Can J Fish Aquat Sci 58:1535-1557

Lasker R (1981) The role of a stable ocean in larval fish survival and subsequent recruitment. In: Lasker R (ed) Marine fish larvae: morphology, ecology, and relation to fisheries. Washington Sea Grant Program, University of Washington, Seattle, p 79-87

Lough RG, Potter DC (1993) Vertical distribution patterns and diel migrations of larval and juvenile haddock Melanogrammus aeglefinus and Atlantic cod Gadus morhua on Georges Bank. Fish Bull 91:281-303

Lough RG, Valentine PC, Potter DC, Auditore PJ, Bolz GR, Neilson JD, Perry RI (1989) Ecology and distribution of juvenile cod and haddock in relation to sediment type and bottom currents on eastern Georges Bank. Mar Ecol Prog Ser 56:1-12

Mac MJ (1985) Effects of ration size on preferred temperature of lake charr Salvelinus namaycush. Environ Biol Fish 14: 227-231

Marshall SL, Parker SS (1982) Pattern identification in the microstructure of sockeye salmon (Oncorhynchus nerka) otoliths. Can J Fish Aquat Sci 39:542-547

Meekan MG, Fortier L (1996) Selection for fast growth during the larval life of Atlantic cod Gadus morhua on the Scotian Shelf. Mar Ecol Prog Ser 137:25-37

Miller TJ (1997) The use of field studies to investigate selective processes in fish early life history. In: Chambers RC, Trippel EA (eds) Early life history and recruitment in fish populations. Chapman \& Hall, London, p 197-223

Mittelbach GG (1983) Optimal foraging and growth in bluegills. Oecoligica 59:157-162

Möllmann C, Kornilovs G, Sidrevics L (2000) Long-term dynamics of main mesozooplankton species in the central Baltic Sea. J Plankton Res 22:2015-2038

Mosegaard H, Titus R (1987) Daily growth rates of otoliths in yolk sac fry of two salmonid species at five different temperatures. In: Kallander SO, Farnholm B (eds) Proceeding of the V Congress of European Ichthyologists, Stockholm. Swedish Museum of Natural History, Stockholm, p 221-227

Mosegaard H, Svedäng H, Taberman K (1988) Uncoupling of somatic and otolith growth rates in Arctic char (Salvelinus alpinus) as an effect of differences in temperature response. Can J Fish Aquat Sci 45:1514-1524

Myers RA, Cadigan NG (1993a) Density-dependent juvenile mortality in marine demersal fish. Can J Fish Aquat Sci 50:1576-1590

Myers RA, Cadigan NG (1993b) Is juvenile natural mortality in marine demersal fish variable? Can J Fish Aquat Sci 50:1591-1598

Neverman D, Wurtsbaugh WA (1994) The thermoregulatory function of diel vertical migration for a juvenile fish, Cottus extensus. Oecologia 98:247-256

Perry RI, Neilson JD (1988) Vertical distributions and trophic interactions of age- 0 Atlantic cod and haddock in mixed and stratified waters of Georges Bank. Mar Ecol Prog Ser 49:199-214

Peterman RM, Bradford MJ, Lo NCH, Methot RD (1988) Contribution of early life stages to interannual variability in recruitment of northern anchovy (Engraulis mordax). Can J Fish Aquat Sci 45:8-16

Post JR, Evans DO (1989a) Experimental evidence of sizedependent predation mortality in juvenile yellow perch. Can J Zool 67:521-523

Post JR, Evans DO (1989b) Size-dependent overwinter mortality of young-of-the-year yellow perch (Perca flavescens): laboratory, in situ enclosure, and field experiments. Can J Fish Aquat Sci 46:1958-1968

Rice JA, Miller TJ, Crowder LB, Marschall EA, Trebitz AS, DeAngelis DL (1993) Growth rate variation and larval sur- 
vival: inferences from an individual-based size-dependent predation model. Can J Fish Aquat Sci 50:133-142

Rogers JS, Hare JA, Lindquist DG (2001) Otolith record of age, growth, and ontogeny in larval and pelagic juvenile Stephanolepis hispidus (Pisces: Monacanthidae). Mar Biol 138:945-953

Rudstam LG, Hansson S (1990) On the ecology of Mysis mixta (Crustacea, Mysidacea) in a coastal area of the northern Baltic proper. Ann Zool Fenn 27:259-263

Salvanes AGV, Giske J, Nordeide JT (1994) Life-history approach to habitat shifts for coastal cod, Gadus morhua L. Aquac Fish Manage 25(Suppl 1):215-228

Secor DH, Dean JM (1989) Somatic growth effects on the otolith - fish size relationship in young pond-reared striped bass, Morone saxatilis. Can J Fish Aquat Sci 46:113-121

Sissenwine MP (1984) Why do fish populations vary? In: May RM (ed) Exploitation of marine communities. SpringerVerlag, New York, p 59-94

Smith PE (1985) Year class strength and survival of 0-group clupeoids. Can J Fish Aquat Sci 42(1):69-82

Sogard SM, Olla BL (1996) Food deprivation affects vertical distribution and activity of a marine fish in a thermal gradient: potential energy-conserving mechanisms. Mar Ecol Prog Ser 133:43-55

Sparholt H, Aro E, Modin J (1991) The spatial distribution of cod (Gadus morhua L.) in the Baltic Sea. Dana 9:45-56

Sundby S, Bjørke H, Soldal AV, Olsen S (1989) Mortality rates during the early life stages and year-class strength of northeast Arctic cod (Gadus morhua L.). Rapp P-V Réun Cons Perm Int Explor Mer 191:351-358

Editorial responsibility: Otto Kinne (Editor),

Oldendorf/Luhe, Germany
Tupper M, Boutilier RG (1995a) Effects of habitat on settlement, growth, and postsettlement survival of Atlantic cod (Gadus morhua). Can J Fish Aquat Sci 52:1834-1841

Tupper M, Boutilier RG (1995b) Effects of conspecific density on settlement, growth and post-settlement survival of a temperate reef fish. J Exp Mar Biol Ecol 191:209-222

Tupper M, Boutilier RG (1995c) Size and priority at settlement determine growth and competitive success of newly settled Atlantic cod. Mar Ecol Prog Ser 118:295-300

Tupper M, Hunte W (1994) Recruitment dynamics of coral reef fishes in Barbados. Mar Ecol Prog Ser 108:225-235

Uzars D, Plikshs M (2000) Cod (Gadus morhua L.) cannibalism in the Central Baltic: interannual variability and influence of recruit abundance and distribution. ICES J Mar Sci 57:324-329

Van der Veer H, Ellis T, Miller JM, Pihl L, Rijnsdorp AD (1997) Size-selective predation on juvenile North Sea flatfish and possible implications for recruitment. In: Chambers RC, Trippel EA (eds) Early life history and recruitment in fish populations. Chapman \& Hall, London, p 279-303

Voss R, Hinrichsen HH, St. John M (1999) Variation in the drift of larval cod (Gadus morhus L.) in the Baltic Sea: combining field observations and modelling. Fish Oceanogr 8:199-211

Wieland K, Zuzarte F (1991) Vertical distribution of cod and sprat eggs and larvae in the Bornholm Basin (Baltic Sea). ICES CM 1991/J:37

Zijlstra J, Dapper R, White J (1982) Settlement, growth and mortality of post-larval plaice (Pleuronectes platessa) in the western Wadden Sea. Neth J Sea Res 15:250-272

Submitted: July 1, 2002; Accepted: July 1, 2003

Proofs received from author(s): August 15, 2003 